\title{
バイオエコノミー時代のバイオテクノロジーの役割\#
}

\author{
柴田大輔* \\ 京都大学・エネルギー理工学研究所
}

（2020年6月16日受理）

\section{The roles of biotechnology in the Bio-economy era}

\author{
Daisuke Shibata \\ Institute of Advanced Energy, Kyoto University, Gokasho, Uji, Kyoto 611-0011, Japan
}

Keywords: $\quad$ Paris Climate Agreement, Decarbonized Society, Renewable Energy, SDGs, ESG investment.

\section{は じめに}

OECD（経済協力開発機構）が，産業革命以降続いてき た化石資源依存から脱却した持続可能な社会の経済活動と して，バイオエコノミーという考え方を2009年に提唱し た. ${ }^{1)}$ OECDは，2030年までには世界のバイオ市場がモノづ くり (工業), 農業, 健康分野で年間 1.6 兆ドルに達すると 予想している. 化石資源に依存した人類の生活が直面する最 大の課題の一つが, 地球温暖化が引き起こすと予想される気 候変動であり, 農業や経済に多大な影響を引き起こすと懸念 されていることが，バイオエコノミ一提案の背景にある.

バイオエコノミーは経済面からの提案であるが，その後の 気候変動に関する議論や現代社会の課題解決に向けた活動 にも影響を与えている.1997年に採択された京都議定書の 段階では, 人類の活動が気候変動を引き起こしていること に関して，一部では懐疑的な見方もあった。しかし，2015 年の気候変動に関するパリ協定では, 産業革命以前と比心゙ て世界の平均気温上昇を「2度未満に抑える」との目標に関 し，196の国と地域の賛同が得られた。2015年には，国連が

\footnotetext{
\#第45回大会シンポジウムの内容を取りまとめた解説.

* = 611-0011 京都府宇治市五ヶ庄

E-mail: shibata.daisuke.h93@kyoto-u.jp

(c) 日本農薬学会
}

2030年までに達成すべき目標として「持続可能な開発目標 (Sustainable Development Goals, SDGs)」を定めた. SDGs の本質は, 化石資源に依存して発展してきた現代社会が抱え る様々な「負の遺産」である気候変動, 環境污染, 貧富の格 差拡大, 飢餓, 紛争などの解消を目指す目標と理解できる. パリ協定と同じ年にSDGsが採択されたことは偶然ではな い. バイオエコノミーに関する国際会議などでは常にSDGs との関連において議論されている.

図 1 には，化石資源依存の社会から脱炭素社会に移行する 際の枠組みとそれを取り巻く経済活動の関係性をまとめた。 パリ協定は脱炭素社会を要請しているが, 単に化石燃料の使 用抑制だけでなく，現代社会が直面する負の遺産を同時に解 消するための枠組みとして, バイオエコノミーに加えて, 資 源を持続可能な形で再利用するサーキュラーエコノミー, 先 進国と発展途上国間の貿易を公平に行うフェアトレードなど の経済活動と共に脱炭素社会を実現させると考えるべきだろ う。ただし，この実現は容易ではなく，政府が支援する仕組 みとして, 公共調達 (後述), 補助金などが必要である.こ れらは税金から出るので, 国民の理解が必要となる。経済界 は，ESG投資や投資撤退の形で後押ししている（後述）。化石 燃料由来のエネルギーを再生可能エネルギーに代替する運動 RE100（Renewable Energy 100\%）に参加する企業が増えて おり, 経済活動そのものが大きな変換点に差し掛かっている. 化石資源に依存した社会からの脱却とは，化石燃料エネル 


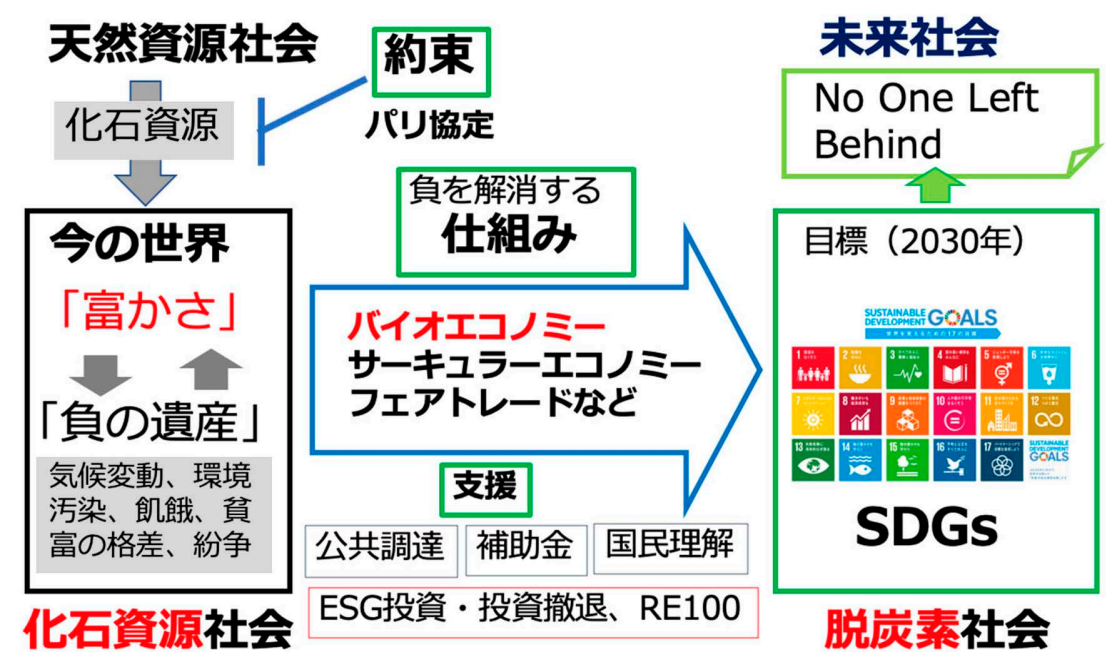

図 1. 化石資源社会から脱炭素社会への移行を取り巻く状況.

ギーを再生可能エネルギーに変換するだけでなく, 現代生活 に不可欠となっている化成品群からの脱却でもある. 持続可 能な炭素源（有機物）である植物バイオマスから化成品代替 物を製造することはバイオエコノミーの主要な課題であり, バイオテクノロジーが期待される所以である.今までのよう な「性能が良いものを作れば売れる」という発想ではなく， 「脱炭素社会に貢献する」ことを前提とした革新的イノべー ションが求められている.

世界の多くの国々では, バイオエコノミー戦略を鮮明にし て，新たなイノベーションによる産業創出の機会であると 捉えている，日本では，2017年に国立研究開発法人新エネ ルギー・産業技術総合開発機構（NEDO）がバイオエコノ ミ一調査報告書 ${ }^{2)}$ をまとめ，2018年6月 21 日には，バイオ 戦略 ${ }^{3)}$ が閣議決定されている。このバイオ戦略では, 課題 設定項目の多くは, 従来のバイオテクノロジーの延長になっ ているケースが多く，エネルギー問題であるとの視点が弱 く, 対応が必要だろう. バイオエコノミーに関する解説とし ては文献4）-6）がある.

\section{1. バイオエコノミー時代の経済動向}

パリ協定以降, 環境（Environment）や社会（Society）や ガバナンス (Governance) への取り組みを投資の際の指標 とするESG投資が広がっている，2019年の時点で， ESG投 資は世界の運用資産の 3 割近く（約 3,400兆円）を占めてい る（日本経済新聞2019年 11 月 10 日）。そのうち半分程度は, 脱炭素社会に向けた再生可能エネルギー投資などの環境関係 である．環境に特化したグリーンボンド（環境債）の扱いも 増えており，2019年で世界での発行額が累積で約 100 兆円 を超えている（日本経済新聞2019年10月25日）。二酸化炭 素の排出量が多い石炭火力発電に対しては評価が㛜しく, 投 資そのものを引き上げるダイベストメント（投資撤退）も
始まっている. 数年前までは日本の銀行の動きは鈍かった が，2020年に入り, 日本の大手銀行による石炭火力発電へ の投資の抑制が検討されている. SDGs債の発行も増えてお り，世界では2018年で18兆5千億円に達している（日本経 済新聞2019年7月 18 日). SDGsに取り組む企業も増えてい るが，環境や社会に対する意識を持ち，どのように行動する かが会社の存続に繋がる状況になっている.

バイオエコノミーの目的が化石資源からの脱却である以 上，バイオ製品の製造過程が化石資源エネルギーに依存して いたのでは意味がない，バイオ製品の製造エネルギーに占め る再生可能エネルギーの比率を高めることが重要であり, 国 としてのエネルギー政策が問われることになる，特に，バイ 才製品を輸出する場合, 問題となる可能性がある，欧州連合 （EU）は，バイオエコノミーを新たなイノベーションによる 産業振興につながるとして積極的に推進している．EUは， 独自の認証制度を駆使して域内のメリットを最大化している ので，バイオエコノミーにおいてもその動向には注目すべき である. EUでの再生可能エネルギーの導入率は高く, 再生 可能エネルギーの割合が低いバイオ製品を排除する認証制度 が成立すると，バイオ製品の性能が優れていたとしても，日 本のように再生可能エネルギーの導入率が低い国で製造した 製品がEU市場に参入できない可能性が出てくる。つまり, バイオ製品の製造にはエネルギー問題を念頭において開発す ることが求められる.

バイオエコノミーの推進には，バイオ由来製品の積極的な 買い上げが初期において必要となる. バイオ由来製品は化成 品に比べて割高なために, 普及が進みにくい.アメリカ農務 省（USDA）では公共調達に際して, BioPreffered制度 ${ }^{7)}$ が あり, 政府が優先的にバイオ由来製品を買い上げ，普及を後 押ししている. 公共調達で割高な製品を税金で購入する以 上, バイオエコノミーの推進の意義を, 再生可能エネルギー導 
入の意義とともに，国民に理解してもらうことが大切になる.

日本ではバイオエコノミーへの取り組みか㳄州などと比べ て遅れており, 産官学での議論が不十分である点は否めな い. 例えば，プラスチックによる海洋污染が話題になってい るが，単に環境問題であるだけでなく，脱化石資源であると の視点から，植物バイオマスの利用をどのように進めるの か，それに伴うコストを誰がどのように負担すべきかなど， 単に政府か政策を決めるだけではなく, 企業, アカデミア, 市民を含めた幅広いステークホルダー間の議論が必要だろ う.

\section{2. バイオエコノミー時代のバイオテクノロジー}

植物バイオマスは, 太陽エネルギーによって生育し, 炭素 循環に組み込まれているという意味で持続可能な社会形成に 必要な原材料である。 バイオエコノミ一時代には，化石資源 から作られる化成品に代わって，植物バイオマスから工業製 品を作ることが求められている．化成品が市場に広く出回る ようになったのは，20世紀半ば以降であるが，現代生活に は不可欠なものとなり，その代替は容易ではない，植物バイ オマスを使うバイオ製品では，化成品の同等品に比べてコス 卜高になることが懸念され，研究開発の進展が遅かった。し かし，バイオエコノミーの時代には，積極的なバイオ製品開 発が求められる。

バイオテクノロジーは, 農業, 工業生産, 医薬品開発と幅 広い分野をカバーするが, 本稿では, 植物バイオマスを使っ たバイオテクノロジーを主に取り上げる.

\section{1. 植物バイオマスとエネルギー問題}

バイオエコノミーを議論する際には，化石燃料からのエネ ルギー代替を考える必要があり, 植物バイオマスをエネル ギ一源として使う際の課題を整理しておく必要がある，以下 では，植物バイオマスは必ずしも効率的な再生可能エネル ギー源ではないことを指摘する。

現代社会が使っているエネルギー量か膨大であることを考 えれば, 植物バイオマスのエネルギーに依存することには無 理がある．人類が火を使用するようになって以来，現在に 至るまで，薪（植物バイオマス）はエネルギー源として使わ れてきた．地上の植物バイオマスが固定する太陽エネルギー $\left(3.0 \times 10^{21} \mathrm{~J} /\right.$ 年) は人類の使用する全エネルギー（3.0× $10^{20} \mathrm{~J} /$ 年）の 10 倍以上なので, ${ }^{8)}$ 植物バイオマスのエネル ギー利用も理論的には可能ではある。しかし，地球上に薄く 広く存在する植物バイオマスを回収し，加工することを含め たエネルギー収支を考えると，植物バイオマスのエネルギー 利用には限界がある。植物バイオマスのエネルギーに関して は文部科学省 HPに掲載されている内嶋善兵衛氏による資料 が参考になる.9

植物バイオマスの主要成分である多糖類（セルロース，へ
ミセルロース）からバイオ燃料を生産する研究開発が盛んに 行われてきた。しかし, 植物の栽培, 収穫, 加工に要する エネルギーと，バイオ燃料に含まれるエネルギーを比較する と，多くの場合にはエネルギー収支はプラスになっていな (、. ${ }^{9)}$ アメリカではトウモロコシのデンプンから，ブラジル ではサトウキビのショ糖から多量のバイオエタノール生産が 行われている。これらは, 経済政策, 農業保護政策としての 側面が強く, また, 食料とエネルギーの競合になっている点 も問題である. ${ }^{10)}$

処分に困る畜産廃棄物や農産廃棄物をメタン発酵させ, 回 収したメタンを燃焼して電気エネルギーを回収するバイオガ ス発電が行われている. ${ }^{11)}$ 規模が小さいためにエネルギー回 収効率は低いが, 発酵残渣 (消化液) に含まれる植物バイオ マス由来の栄養分（リン酸など）を循環的に使うことに意義 がある.

このように, 植物バイオマスはエネルギーとしては利用効 率が低いので, 再生可能エネルギーとしての利用には限界が ある. しかし, 地球上で普遍的に, 豊富に存在するので, 地 域性，社会性などを考慮して利用することには意義がある。

植物バイオマスは, 栽培と加工などに多量の化石燃料由来 エネルギーを利用していることに留意すべきである．現代 社会の農業生産では耕運，肥料，収穫，保存，運搬に多く のエネルギーを使っており，それらのエネルギー量を少なく することは重要な課題である．2020年1月26日に日本政府 で閣議決定された「戦略的環境イノベーション戦略」のなか には, 農業での化石燃料由来のエネルギー利用を削減するた めに,「ゼロエミッション農林産業」が研究開発項目として 入っている. ${ }^{12)}$

\section{2. 再生可能エネルギー導入の意味}

植物バイオマスからのエネルギー生産に限界や制限がある 以上, 植物バイオマスの栽培から加工に至るまでに必要な工 ネルギーを他の再生可能エネルギーに依存することになる. 当面は, 現実的な選択肢として化石燃料エネルギーを使わざ るを得ないが, 再生可能エネルギーに代替することが常に強 く求められる. 企業活動で使うすべてのエネルギーを再生可 能エネルギーに変えることを宣言するRE100運動に参加す る企業は大手を中心に増えており, バイオテクノロジー分野 も例外ではない.

再生可能エネルギーの問題は本稿の範囲を超えるが，バイ オエコノミー時代にはエネルギーを意識した研究開発が求め られるので, 再生可能エネルギー導入の現状を簡単に紹介す る. 農業生産への再生可能エネルギーの導入に関しては拙著 を参照されたい. ${ }^{13)}$

2020 年現在では, 風力発電, 太陽光発電のコスト（設備 の設置, 維持, 廃棄までも含む) は, 世界的には石炭火力発 電のコストよりも安くなっている. 2000年代までは再生可 


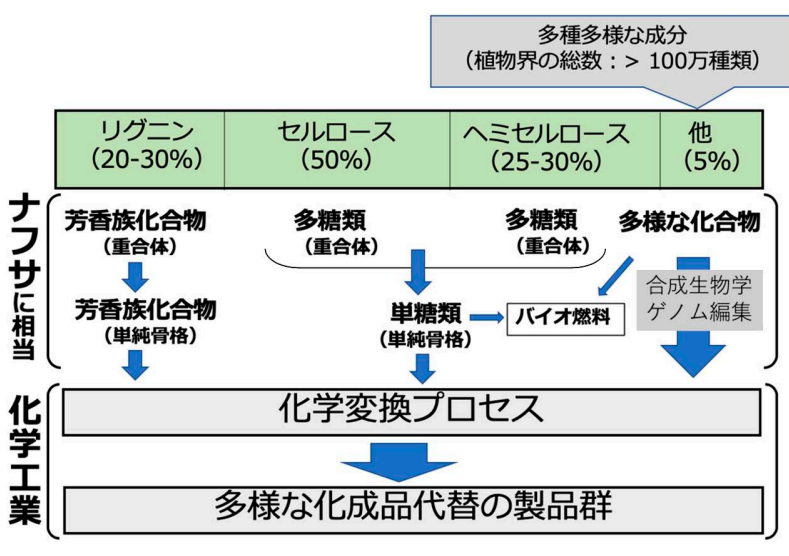

図2. 主要バイオマスからの化成品代替製品の製造概略.

能エネルギーは高コストであり, バイオエコノミーを推進 する際の最大のネックの一つであったが，2012年ごろから， 太陽光発電, 風力発電から得られる再生可能エネルギーの生 産コストは劇的に低下した. 日本での再生可能エネルギーの 生産コストはまだ高いが，いずれは低下するだろう.

日本では，東日本大震災の影響で原子力発電の運用が難し く, 化石燃料依存が続いており, 再生可能エネルギーの導入 は欧州に比べて遅れている.バイオエコノミーの推進には, 再生可能エネルギーの導入への積極的な取り組みが必要とな る. 再生可能エネルギーの導入は, 様々な要因が入り組み, 必ずしも容易ではないが避けて通ることはできない。

バイオ製品が脱炭素社会に受け入れられるためには，植物 バイオテクノロジーの研究開発において, 全工程でのエネル ギー利用を考慮して, 再生可能エネルギーの導入が容易な工 程を積極的に選ぶことが求められる．そのことがバイオ製品 の社会受容につながる.

\section{3. 炭素源としての植物バイオマス}

植物バイオマスは化成品代替物を作り出すための炭素源 （有機物）として使うことができる. 地球上の全植物バイオ マスの内訳は, セルロース, ヘミセルロース, リグニンがそ れぞれ約 $50 \%$, 約 $20 \%$, 約 $20 \%$ である。 セルロース，へミ セルロースは加水分解によって単糖として使うことができ る.リグニンは芳香族環構造を持った不規則な重合体である ので, 分解物は芳香族化合物や炭化水素化合物などの混合物 となる．規模の大きな化成品代替物の生産には，これらの分 解物を利用することになる（図2）. 今後は，微生物利用に よるバイオテクノロジーや化学工業テクノロジーによる化成 品代替物の生産技術の研究開発が進むだろう.

再生可能エネルギー導入コストの低下（上述）は, 大気 中の二酸化炭素を再生可能エネルギーを使って固定して化 成品代替となる有機物製造に使う道を開くことになる。化 石資源の燃焼によって, 今まで, 大気中に放出されていた 二酸化炭素を回収し, 再生可能エネルギーを使って有機物 （炭化水素）を製造する研究（Carbon Capture, Utilization and Storage, CCUS）が進んでいる.「戦略的環境イノベー ション戦略」にもCCUSが開発項目に入っている. ${ }^{12)}$

植物バイオマスと CCUSの利用は競合する考え方である. 前者は人類が利用してきた長い歴史があり, かつ, 地球上 に 20 万種類以上の植物が存在しており, 途上国であれ先進 国であれ利用が可能である，後者は今後の技術であることか ら, 当面は競合は生じないであろう. 植物バイオマス利用で は, 最先端の遺伝子工学により様々な化合物を作り出せる可 能性があり, CCUS とは異なる分野での技術開発が期待され る.

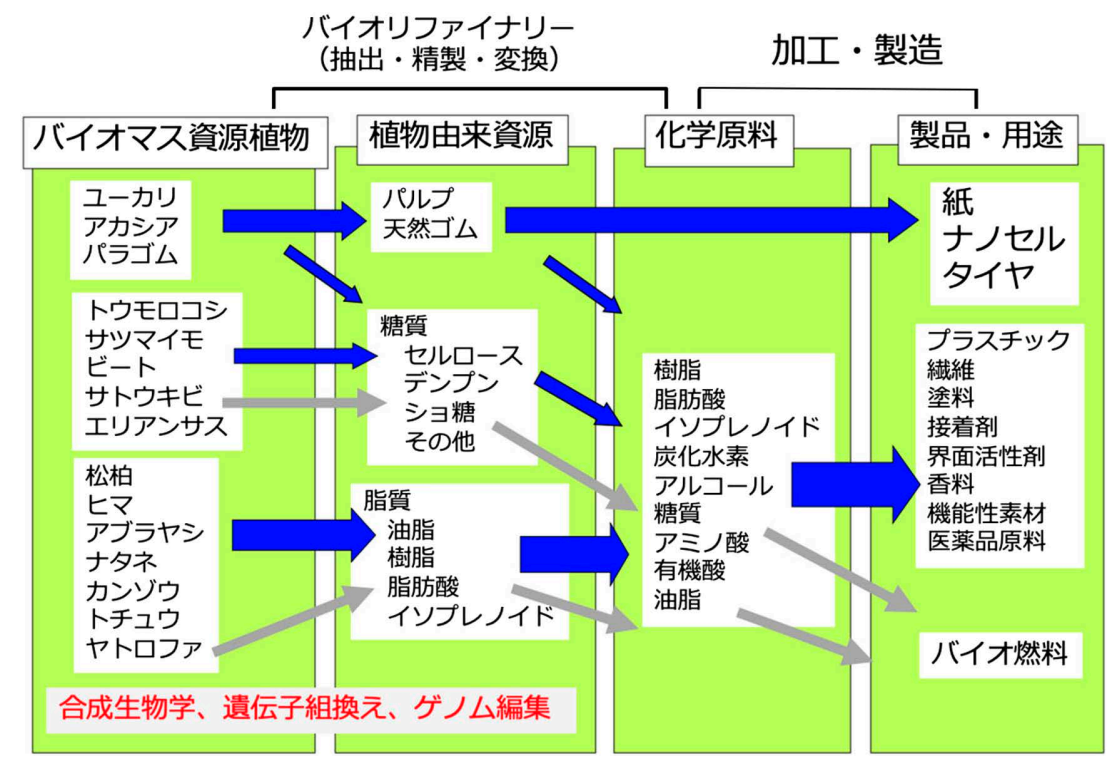

図3. 多様な植物バイオマスの利用プロセス 


\section{4. 植物バイオテクノロジーの課題}

植物バイオマスの利用は, 伝統的な木材利用から最先端の 遺伝子組換え技術を用いたものまで多種多様である.図3に は，植物バイオマス利用の主だった植物種と製造過程をまと めた，従来の手法で製造されている製品に関しては，製造工 程での再生可能エネルギーの導入率の向上が求められる. 化 成品との価格競争で不利な製品については, 公共調達, 補助 などの支援が必要である。しかし，それらの支援は国民の税 金を使うために, バイオエコノミ一時代での工業生産品を社 会でどのように支えるのかを議論したうえでの合意形成が必 要となる.

遺伝子組換え技術，ゲノム編集技術などの最先端テク ノロジーの活用が期待される. 国際アグリバイオ事業団 （ISAAA）の報告書によれば2017年の遺伝子組換え作物の栽 培面積は 1 億 8980 万h h となっている. ${ }^{13)}$ ただし，バイオエ コノミ一時代に求められる高度な製品開発に関しては, 植物 バイオマスの研究開発は今後の課題である. 国内では, 植物 バイオマスの高度利用を含めたスマートセルプロジェクト （NEDO, 2016-2020年度）などがある. ${ }^{15)}$

植物バイオテクノロジー分野での技術開発に関しては, 代 謝改変のための A I (人工知能) を用いたゲノム情報解析, メタボローム解析, 合成生物学の手法が重要になると予想さ れる. 特に, メタボローム解析 ${ }^{16,17)}$ は, 農作物の成分評価, 農薬の生態系への影響評価などに威力を発揮するだろう.

一方で，植物への遺伝子導入は一部の植物で成功している だけであり, 多くの工業原材料を生産している植物に応用で きる状況にはない. その主な原因は, 遺伝子導入後の再分化 技術が試行錯誤に依存しており, 多くの場合, 再分化条件を 見出すことができていない. 再分化の遺伝子レベルでの解 明が進めば，植物種の壁を超える技術の発展が期待できる. また, 動物研究では, iPS研究で知られているょうに, ク口 マチン制御（染色体構造の制御）が遺伝子発現に重要である が, 植物でのクロマチン制御の研究は少ない. クロマチン制 御による植物代謝工学は今後の重要な研究分野となるだろう.

\section{ま と め}

化石資源に依存した社会から脱炭素社会に移行するための 経済体系としてバイオエコノミーが提唱されている. 同時 に, 化石資源社会の負の遺産である環境問題, 貧富の格差な どを解消するためのSDGsが国連で提唱されている，バイオ エコノミーやSDGsを支える経済活動としてESG投資, 環境 債などが広がっており, 企業活動において脱炭素社会を目指 すことが求められている. 再生可能エネルギーは最も安価な エネルギー源となっており, バイオテクノロジー分野でも再 生可能エネルギーの活用を意識した研究開発が求められる. 植物バイオマスは化石資源を代替する炭素源（有機物）を提 供しており, 植物バイオテクノロジーによる化成品代替製品
の生産に関するイノベーションと産業創出が期待される.

\section{謝辞}

バイオエコノミーに関しては, 一般財団法人バイオインダ ストリー協会の坂元雄二氏, 藤島義之氏（現在, NEDO), (株)三菱ケミカルリサーチ増田宏之氏らとの意見交換を踏ま えて記述しており感謝いたします。

\section{引 用 文 献}

1) OECDバイオエコノミー提案：https://www.oecd.org/futures/ longtermtechnologicalsocietalchallenges/42837897.pdf（2020年 5 月31日閲覧)

2) NEDO報告書：バイオエコノミーの現状分析とスマートセル が変える未来像に関する調查 https://www.nedo.go.jp/library/ seika/shosai_201708/20170000000796.html（2020年5月31日閲 覧)

3) バイオ戦略 2019 : 令和元年6月11日統合イノベーション戦略推 進会議決定 https://www.kantei.go.jp/jp/singi/tougouinnovation/ $\mathrm{pdf} /$ biosenryaku2019.pdf (2020年5月31日閲覧)

4）五十嵐圭日子：バイオサイエンスとインダストリー $75,344-348$ (2017).

5）増田宏之，小林 幹：アグリバイオ 2, 1164-1167 (2018).

6）柴田大輔：バイオサイエンスとインダストリー 77, 64-67 (2019).

7) アメリカ農務省（USDA）BioPreffered制度：https://www.bio preferred.gov/BioPreferred/(2020年5月31日閲覧)

8）瀬戸山 亨, 堂免一成: 光触媒/光半導体を利用した人工光合 成, 堂兔一成, 瀬戸山 亨監修, エヌ・ティー・エス社, p. 5, 2017.

9）文部科学省 3. 各論 付属資料-1 (第3章関係)：https://www. mext.go.jp/b_menu/shingi/gijyutu/gijyutu3/shiryo/attach/1287193. $h t m （ 2020$ 年 5 月 31 日閲覽）

10）松永和紀：メディア・バイアス, 光文社, pp. 217-232, 2007.

11）村田 武, 河原林孝由基: 自然エネルギーと協同組合, 筑波書 房, pp. 1-18, 2017.

12) 戦略的環境イノベーション戦略: 令和 2 年 1 月 21 日統合イノ ベーション戦略推進会議決定 https://www.kantei.go.jp/jp/singi/ tougou-innovation/pdf/kankyousenryaku2020.pdf（2020年5月 31 日閱覧)

13) 柴田大輔: 生存圈研究 15, 19-27 (2020).

14）国際アグリバイオ事業団（ISAAA）の報告書：https://www. isaaa.org/resources/publications/briefs/53/executivesummary/ $\mathrm{pdf} /$ B53-ExecSum-Japanese.pdf (2020年5月31日閲覧)

15）スマートセルインダストリー: https://www.nedo.go.jp/content/ 100884792.pdf (2020年5月31日閲覧)

16) Iijima, Y. Nakamura, Y. Ogata, K. Tanaka, N. Sakurai, K. Suda, T. Suzuki, H. Suzuki, K. Okazaki, M. Kitayama, S. Kanaya, K. Aoki and D. Shibata: Plant J. 54, 242-250 (2008).

17) N. Akimoto, T. Ara, D. Nakajima, K. Suda, C. Ikeda, S. Takahashi, R. Muneto, M. Yamada, H. Suzuki, D. Shibata and N. Sakurai: Sci. Rep. 7, 1243 (2017). 


\section{略 歴}

柴田大輔（しばた だいすけ）

生年月日：1954年2月 21 日

最終学歴: 京都大学大学院農学研究科博士課程修了（農学博 士）

研究テーマと主な職歴：バイオテクノロジー全般とそれを支 える基盤技術開発とエネルギー問題. 三井業際植物バイオ研 究所主任研究員, かずさDNA研究所研究部長を経て, 現在, 東北大と岐阜大で客員教授, 京大エネルギー理工学研究所お よび生存圈研究所で特任教授, バイオインダストリー協会理 事.

趣味：新しいことにチャレンジ. 